UDC 930.1(092)(477)

DOI: $10.24919 / 2519-058 x .7 .132753$

Ivan KUTSYI, orcid.org/0000-0002-3556-1962 Ph D hab. (History), Associate professor of History of Ukraine Department Ternopil Volodymyr Hnatiuk National Pedagogical University (Ukraine, Ternopil)kutsyy@ukr.net

\title{
THE RECEPTION OF EUROPE/WEST IN THE SCIENTIFIC HERITAGE OF THE MYKHAILO MAKSYMOVYCH
}

In the articles Mykhailo Maksymovich' civilization identity has been considered. The specificity of the scholars' civilization views has been analyzed through the twofold category "our: foreign», the basic civilization images on his mental map have been outlined, their content filling and axiologic loading has been examined. Also, the attention has been focused on the scientist's interpretations of a historical image of Europe/the West as a «foreign" civilisation to the Slavs. The role of M. M. Maksymovych in the process of Ukrainian civilization identification has been summed up.

Key words: M. Maksymovych, the West, Europe, civilisation, image, identity, Slavs, the Slavic land, Poland.

Іван КУЦИЙ,

доктор історичних наук, доиент кафедри історії України

Тернопільського національного педагогічного університету імені Володимира Гнатюка (Україна, Тернопіль) kutsyy@ukr.net

\section{РЕЦЕПЦІЯ СВРОПИ/ЗАХОДУ У НАУКОВІЙ СПАДЩИНІ МИХАЙЛА МАКСИМОВИЧА}

У статті розглянуто ичивілізаційну ідентичність Михайла Максимовича. Проаналізовано спечифіку чивілізачійних поглядів вченого крізь призму двоєдиної категорї̈ «свій-чужсий, окреслено основні цивілізаційні образи на його ментальній карті, простежено їхнє змістове наповнення та аксіологічне навантаження. Акиентовано увагу на інтерпретачіях вченим історичного образу Свропи/Заходу як «чужсої слов'янам циивілізації. Узагальнено роль М. Максимовича у процесі тенези української ичвілізаційної ідентичності.

Ключові слова: М. Максимович, Захід, Європа, цчивілізація, образ, ідентичність, слов'яни, Слов'янщчина, Польщ̧а.

The problem statement. In the contemporary intellectual space of Ukraine the categorical thesis-ideologeme about the purely European belonging of Ukraine's cultural-civilization values is widespread. By ascertaining this no views on civilization of the persons and even the whole intellectual trends of the Ukrainian past, who or which in due time stuck to the alternative to the Europe oriented doctrines are taken into account. It is to such persons that Mykhailo Maksymovych belongs.

Research analysis. Though the heritage of this scientist, who was a remarkable figure in the Ukrainian and Russian historiographic traditions of the XIX century, is one of the very well studied, the problem of his civilization orientations is not clarified in the Ukrainian 
science. It suffice here to mention the following fact: among a significant number of the researches devoted to M. Maksymovych' multilateral activity, not a single one treated his view on the civilization belonging of Ukraine. The purpose of the article. Eventually, the outlining of the problems of the aforementioned Ukrainian scientist image of Europe makes up the purpose of this article.

Presenting main ideas. M. Maksymovych, as well as the majority of his contemporaries in the Ukrainian and Russian intellectual environment, identified himself with the Slavic world as a separate and autarkic cultural-civilization community. In his texts «his» civilisation is terminologically designated as the Slavic world, the Slavs, the Slavic tribe, Slavic circle, Slavic elements, and most frequently as Slovyianshchyna (the «Slavonic civilization»). Within the boundaries of the Slavic world, M. Maksymovych and his contemporaries singled out somewhat narrower cultural-civilization community, defining it as the Rus' world. To it the whole East Slavic orthodox space was included. The Slavic world in their consciousness appeared to be a civilization antagonistic to the West, Europe, or the so-called Germanic world. Thus, they thought of the history of the Slavic peoples as perpetual - since the times immemorial - opposition to aggressive and enemy pressure from the Germanic peoples.

M. M. Maksymovych' formation as a scientist took lace during an epoch, in which - according to Andrzei Valitsky - «the attitude to the values, symbolised by a word «the West», became the main criterion of ideological differences» (Валіцький, 1998: 69). After all, M. Maksymovych can be considered as one of the first representatives of the Ukrainian Slavofiles (pan-Slavists), for whom, in Mykola Riabchuk's words, «xenophobia or, at least, suspicion to all foreign, non-Slavic» was characteristic (Рябчук, 2000: 78). Already in his early studies he evidently outlined «his» civilization identity. He accurately and unequivocally inscribed the representatives of the «Rus' tribe» into a wider, super-ethnic context alias Slavic. Everything that was connected with the Slavic world he accepted as «his», whereas all that was beyond the defined space (that is, was «not Slavic»), was, certainly, considered as «not his», «foreign» to him, or even as «inimical». Although in M. Maksymovych' works no strict definition as to the content filling of civilization identification of the Slavic world, many indirect mentions of the basic grounds on which the author conducted his civilization identification policy.

Despite his prime attention to the image of «his» civilisation (that is, the Slavic world), M. Maksymovych paid much attention to the image of Europe/the West. His used a remarkable terminological variety in the description of the latter's vital space. Most frequently he designated it as the West. The toponym Europe he used mostly in geographic-spatial context. He used such notions as the foreign west, the Latin West, the German circle. Generally speaking, M. Maksymovych often identified all European with all German and Germanic. as a matter of fact, he wrote that in Mykhailo Lomonosov's outlook «ancient Slavic world, Latin world and Germanizm» had merged (Максимович, 2004d: 51). The Swedes, Norwegians, Englishmen, and Goths the scientist also readily called «the peoples of the Germanic tribe» (ibid.). The perception of Europe/ the West as «foreign vital space» is most distinct in his expressions like «in our East and the European West» (Максимович, 2004d: 61). M. M. Maksymovych' reception of the West as hostile to the Rus'/Slavic world can be felt in his many other references: «The Southern Rus' (Ruthenia), having suffered so much from the eastern enemies, also suffered much the western enemies» (Максимович, 1877a: 210).

The scientist regarded Napoleonic intrusion of 1812 into Russia as aconcrete display of the western military aggression. In «The Bubniv company» he metaphorically wrote about 
those events: «The Russian land was boiled and waving like the sea in an attempt to get rid of the grandiose idol of the west with his hordes» (Максимович, 1876a: 825). A testimony of the fact that the scientist perceived Napoleonic empire as an embodiment of all the West is obvious from the next quotation: «on the field by Borodino the force of the Rus' had fought with the force of the West» (Максимович, 1876a: 824).

A menacing danger to the integrity and autarky of the Slavic world M. Maksymovych saw not so much in the West's military-political expansion, as in its cultural influences. Therefore, he negatively estimated the European cultural-educational tendencies in the Ukrainian historical process. So, Feofan of Prokopovych' verses written in the Latin language the scientist ironically called «the academic games» (Максимович, 1877c: 47). In his works «About the Laura Mohyla school», in the XVII century into the ancient Rus'-Slavic tradition «the learning of that time European West was introduced, considerably decorated with paganism or heathenry of the classical Helleno-Latin antiquity. This learning was accepted as the external condition sine qua non for the development of our education». So, notwithstanding its external character, M. Maksymovych regarded the process of the West European cultural-educational influences as a menacing intrusion of the «foreign» within the sphere of the «his own». Later he would accentuate on a negative reaction of the Rus' culture to this western intrusion: «But the Rus' mind then already saw both the necessity and possibility of eliminating from it everything that belonged to it [the foreign culture] as an image of the mind which had not yet been clarified by the divine truth and to turn it into its own Christian enlightenment» (Максимович, 1877a: 213). As can hardly be doubted, the scientist saw a deviation from the bases of true Christianity in the European cultural tradition.

In his fundamental study «A history of the ancient Rus' literature» M. Maksymovych described a tendency of the «striving to ger on European lines» in cultural-educational development of the Russian empire from Peter I to Alexander I. in a rather veiled form. The author critically underlined that, even despite the domination of the West European education, still the «original elements of life did not stop being brightly manifested in this period» (Максимович, 1880a: 353). The scientist paid attention to the antagonistic character of the interaction of the European and pan-Slavic worlds in cultural-intellectual processes: «These two different domains united in the Rus' mind not peacefully» (Максимович, 1880a: 354). In an entirely approving tone he characterised the contemporary to him cultural tendency of Russia, which «in our enlightened time at last /.../ returned to its East Rus world». M. Maksymovych drew a periodical scheme of the historical development of the Rus culture. 'The cultural-civilization influences on it at different historical stages became the main criterion of his periodization. The scientist confirmed as follows: «Thus, in comparison with the main influences on the enlightenment in the Rus' world, it is possible to call the ancient period as Greek-Eastern or, more exactly, Greek-Slavic, the middle period should be called Greek-Latin-Slavic, and the new one can me called New-European, whereas the contemporary period marks the beginning of an authentic Rus' (Rus') one» (Максимович, 1880a: 354). Here M. Maksymovych summarised, that «Russia had gradually and in due time bypassed all the sky of the enlightened Christian world, and now consciously entered this period the its great life, in which it should open all the depth and completeness of its spirit and express in full the quality of its Rus' populace». As is clear, the scientist here in a neutral-tolerant tone referred to the «foreign» (including those of the West) influences on the cultural development of Rus' world. Furthermore, he saw the main essence and positive final result of the historical development of the Rus'/Slavic world in turning from the «foreign» to the original «vernacular» 
bases. It is necessary to notify that in the aforementioned work the author's veiled thoughts about the negative influence of the European West on the Russian empire can be discerned between his lines. Actually, their frank statement would have induce him to more critically estimate the activity of the Russian emperors-«Europeanizers», such as Peter I, Catherine II, and Alexander I. But such statements, certainly, would have caused suspicions in his political unreliability. At the same time, M. Maksymovych ascertained that «The south-eastern Slavs were subjected to more various influences of the foreign people, either Asian, or European» (Максимович, 1880a: 454).

Of great interest for the contemporary biographers are also M. Maksymovych' not public sentences about the West, which are void of self-censorship and scientifically-ethical factors. So, in a letter to O. Bodpanskyi he called the Latin language «barbarian Latin» (Максимович, 2004a: 40). Prononcing in 1862 upon a preponderance of the «newly elected Germans-educators» in the intellectual life of the Russian empire, he emphatically summarised so: «Probably, even within the space of the Rus' world the Slavic tribe is doomed never to get liberated from from the German captivity» (Максимович, 2004a: 59). Hence, of the Ukrainian historians M. Maksymovych most consecutively adhered to the view of Europe/ the West as the «foreign» and «hostile» for the Slavic peoples environment.

M. Maksymovych considered Catholicism as distinguished sign of «the West». In this phis phenomenon he implied a much broader sense, than just religious dogmas and the dominating in the West confession. The image of Catholicism the scientist perceived as a political and cultural community of the West European peoples, as a complete mega-structure. However, the scholar seldom took into consideration the internal differentiation, non-uniform ethnic-national, dynastic, and political construction of the Catholic space. The Catholic world arose in his image of civilization rather as structurally complete and homogeneous, contrary to a mosaic of the peoples, countries and monarchies competing and conflicting with one another. His perception of Catholicism as an attribute of the West M. Maksymovych expressed in references to it as a «western faith» (Максимович, 2004d: 67). Other his thoughts are self-expressive, like that «numerous encroachment of Rome which did not abandon its intentions to involve Russia under the papal power» (Максимович, 2004b: 153). According to the scientist, Feodosiy Pecherskyi «protected the Grand Prince Iziaslav from the temptations of the powerful ruler of the West», that is, from Pope George VII (Максимович, 1877b: 220). M. Maksymovych considered the later ages as «a heavy time for western Rus' over which the western confession-driving tempest eventually raged» (Максимович, 1877b: 235).

Separately it should be stressed, that within the limits of a collected image of Catholicism M. Maksymovych (as well as his contemporaries) accused the main originator of «the western threat» alias the Jesuit order. He wrote that «the spirit of animosity through the lips of Jesuits tirelessly whispered in the ears of the Poles of confessional persecutions and unreasonable arrogance» (Максимович, 2004e: 261). In his other work the scientist noticed that Jesuits restored Catholicism in Poland, «working not for the sake of the Christian faith, but purely for the papal power, thinking only about the Roman tiara and without a thought of the Polish crown» (Максимович, 2004f: 376). Most expressively M. Maksymovych estimated Jesuits as carriers of the western civilization' bases in his study «The Bubniv company»: «The reformatory new thinking /.../ opened Jesuits the road to catch in their nets the new generations of western Rus' princes who, admiring the cunning and fraudulent doctrine of these western wise men, /.../abandoned the piety of their ancestors and distanced themselves from the Orthodox Rus' as dust from the earth, drifted on it by a whirlwind» (Максимович, 1876a: 
750). So, the order of Jesuits M. Maksymovych represented as the main tool of introduction of the western cultural-religious values into Rus' and, on the whole, in the Slavic world.

If the image of Catholicism with all its compounds or derivative phenomena arose as a spiritually-religious component of Europe/ the West, the other, not less significant components of this civilization image were represented by separate «western» (first of all, Germanic) peoples. One of such peoples which name is invariably present at discussions about civilization identity, were annalistic Varangians. Actually, the discussions over the Varangian or Norman question were among the most significant problem for both Ukrainian, and Russian historical sciences in the XIX century.

Yet in his early work «From whence the Rus' land derives» M. Maksymovych interpreted the Scandinavian Varangians not just as a tribe «of strangers», but as the representatives of entirely different from the Slavs cultural-civilization environment: «the Varangians spoke a different language and were a folk different from the Slavs» (Максимович, 2004d: 81). Hе accurately pointed out the belonging of the Varangians to the «western» civilization: «In the middle of the XI century the word «Varangian» designated «western» «i. e., everything opposite to the Greek-Eastern and Slavic-Rus'» (Максимович, 2004d: 81). Further on in the text of the aforementioned work the author wrote this statement: «the Varangian faith is called the western or Latin faith, contrary to the Yrthodoxy of Rus'. The Varangian and Latin for him [Feodosiya Pecherskyi. - I. K.] is the same /.../. Yet before Nestoru Rus' men looked at a Varangian as at a western dissenter» (Максимович, 2004d: 82).

In «A history of the ancient Rus' literature» M. Maksymovych distinctly outlined the image of a Varangian as «a stranger» who embodied everything western: «The name Varangian was always associated the notion of an «offshore man», a stranger, a foreigner and, last but not least, a confessional dissenter: thus, in the XI and XII centuries the western or Latin confession was also called Varangian; a Latinist and and a Varangian were identical words». And further on the scientist specified a successive identity of the notions of the Varangians and the Germans in the designation of the quality «western»: «From the XIII the name «Scandinavians» began also to mean «Germans» which during the Middle Ages ubstituted the name of «Varangians»: the Latin faith was already called German, and with this name they began - quite indefinitely - designating not only all strange, all western, but also all foreign, all belonging to foreign languages» (Максимович, 1880a: 369). The scientist placed emphasis on the fact that an Ancient Rus' annalistic tradition accurately told the Varangians, the strangers to the East Slavic lands, and the Rus' men. While recognising in the former the Germans-Scandinavians, M. Maksymovych called the latter Pomoria-Baltic Slavs, that is, «fellow tribesmen». Although he traced many common features between these two tribes, he, all the same, allocated them into different - «foreign», «western» and «near ones», that is, «Slavic» civilization communities: «But in relation to their language and nationality, they were different: therefore, an influence of the Rus' on the East Slavs, in our understanding, was other, much closer and successful, than influences of foreign to them Varangians» (Максимович, 1880a: 371). The scientist noted also an assimilating influence of the Slavs on the Germans-Varangians: «The Varangians of Scandinavia, on order not to be strangers in our native land, had to accept its Slavic-Rus' nationality and lose their own German one, and still to a greater extent than the Normans lost theirs in western Europe» (Максимович, 1880a: 371). Hence, M. Maksymovych - to an extent - recognised the influence of western civilization («Varangian milieu») on the development of life in Ancient Rus'. Nevertheless, he did not give any definite value to this fact. As an original counterbalance to these influences he 
singled out the Byzantine («Greek-Christian milieu») cultural-civilization influence. The scientist also paid attention, that the western/German influence on the Rus' world had a weighty importance for old Novgorod which « thanks to the relations with the Germans adopted from them more the western life, than the other areas of Rus'» (Максимович, 1880a: 383).

There are hardly reasons to assert that images of Europe/the West in M. Maksymovych' view had a completely negative colouring. The scientist did not go entirely beyond the borders of the established during the Enlightenment epoch o mental map on which «civilized» Europe was opposed to «barbarous» East. In his texts some indirect facts can be found which certify the author's views at Europe as the «enlightened», «cultural», and «civilized" world which positively contrasts against the «eastern barbarity».

Poland, which in his system of civilization images of «the Slavic East - the Germanic West" took a special place, also was in the focus of M. Maksymovych' scientific attention. In his historical texts the thought about «the western» recreancy of Poland was expressively enough displayed. Actually, the scientist was one of the first in the Ukrainian historiography who acquired the Slavofile thesis of the Slavic world and its transition to the side of the Catholic West. He characterized Poland as «the first «pro-Polish» representative in the «Slavic» milieu» (Максимович, 1876a: 750). In the historical concept of the scientist Poland was treated as an initially Slavic-Orthodox country and only in due course it became a leading representative of western Catholicism in the Slavic space: «At first it had accepted east Orthodoxy from the common to the Slavs teachers, but then the Catholicim took over in it» (Максимович, 1876a: 750). The situation, «when Poland so forcefully and ruthlessly tore off true children of the Orthodox church», the scientist interpreted as a display of the «western tempest of confessional reprisals». Thus, he considered Poland both the victim, and the tool of this «most western tempest». Poland, in his words, «drove western Rus' in that same net in which it itself had been caught by Jesuits» (Максимович, 1877b: 235). He valued King Sigizmund III as « brought up by Jesuits and afflicted with their spirit» (Максимович, 1876a: 750). The hint on mastering by Poland of immoral values of the West is traced in the statement about the court «of the mercenary and immoral queen Bona» (Максимович, 1876b: 175). Here M. Maksymovych, not without irony, responded to the election for the Polish crown of a representative of the West European dynasty: «Free in the election of kings Rzecz Pospolita, after it had more than a year and a half worried about its king, elected itself the king who had been a of the Bartholomew night, the 22 year old Henry Valois who four months later fled from Krakow secretly as a night robber, having taken the Polish crown away with him to Paris /.../ At night chosen, he had arrived also at night and went away at night» (Максимович, 1876b: 177). Dwelling upon «Poland western choice», M. Maksymovych reminded about its Slavic root and initial language -cultural cognition with Rus'. He wrote about the Polish language that it «is of one-breed with that of Rus', having yet not lost then its young freshness under the difficult scholasticism of Jesuit Latin» (Максимович, 1876c: 208). M. Maksymovych very clearly expressed his thought on Poland as the tool of expansion of the West to the East is seen in this fragment» Poland, having taken hold of western Rus' and having given in to Jesuits, restored the Catholicism and depressed other Christian confessions. By these means it restored Catholicism among not only among its basic Polish people, having strongly undermined the Reformation in it, but also carried out an unhappy revolt also in the Rus' areas attached to it» (Максимович, 1876c: 208). M. Maksymovych regarded the cultural Rus' cultural tradition in the Polish and Latin language in the times of Rzecz Pospolita as «spoilt» by influences of western/Latin inspirituality. 
Conclusions. Thus, M. M. Maksymovych' scientific-historical heritage should be considered as a powerful source of studying civilization identity of the representatives of Ukrainian intelligentsia of the XIX century. His historical views and beliefs most consistently displayed the world outlook bases of adherents of the Slavic identity and evidently outlined their relation to Europe/the West. Despite some inconsistent positions, M. Maksymovych actually outlined a paradigm of the further development of the Ukrainian civilization identity almost for whole XIX century. With his works, M. Maksymovych contributed both to a conceptual distinction civilization of a civilization image of the West and to its distribution among the readers' audience.

\section{BIBLIOGRAPHY}

Валіцький, 1998 - Валіцький А. В полоні консервативної утопії: Структура і видозміни російського слов'янофільства. К.: Основи, 1998. 710 с.

Максимович, 1876а - Максимовичъ М. Бубновская сотня // Собраніе сочиненій М. А. Максимовича. Томъ І. Отдълъ историческій. К., 1876. С. 747-834.

Максимович, $1880 \mathrm{a}$ - Максимовичъ М. Исторія древней русской словесности // Собраніе сочиненій М. А. Максимовича. Томъ III. Языкознание. История словесности. К., 1880. С. 346-479.

Максимович, $1880 \mathrm{~b}$ - Максимовичъ М. Критико-истоическое изсльдованіе о русскомъ языкъ // Собраніе сочиненій М. А. Максимовича. Томъ III: Языкознание. История словесности. К., 1880. С. 3-24.

Максимович, 2004a - Максимович М. Листи / Упор. і вст. ст. В. Короткого. К.: Либідь, 2004. $312 \mathrm{c}$

Максимович, 2004b - Максимович М. Объ участіи и значеныи Кіева въ общей жизни Россіи // Максимович М. Вибрані твори з історії Київської Русі, Києва і України. К.: Вища школа, 2004. С. $144-158$

Максимович, $1877 \mathrm{a}$ - Максимовичъ М. О лаврской могилинской школь // Собраніе сочиненій М. А. Максимовича. Томъ II: Отдълы: историко-топографическій, археологическій и этнографическій. К., 1877. С. 210-215.

Максимович, 2004c - Максимович М. О мнимомъ запустънии Украины въ нашествіе Батыево и населеніи ея новопришлымъ народом (Письмо М. П. Погодину) // Максимович М. Вибрані твори з історії Київської Русі, Києва і України. К.: Вища школа, 2004. С. 130-141.

Максимович, $1877 \mathrm{~b}$ - Максимовичъ М. О надгробияхъ в Печерскомъ монастыръ // Собраніе сочиненій М. А. Максимовича. Томъ II: Отдълы: историко-топографическій, археологическій и этнографическій. К., 1877. С. 216-237.

Максимович, 2004d - Максимович М. Откуда идеть Русская земля, по сказанію Несторовой повъсти и по другимъ стариннымъ писаніямъ русскимъ // Максимович М. Вибрані твори з історії Київської Русі, Києва і України. К.: Вища школа, 2004. С. 46-115.

Максимович, 1876b - Максимовичъ М. Письма о князьяхъ Острожскихъ (Къ графинъ А. Д. Блудовой) // Собраніе сочиненій М. А. Максимовича. Томъ І: Отдђлъ историческій. К., 1876. С. $164-195$.

Максимович, 1876c - Максимовичъ М. Родословныя записки кіевлянина // Собраніе сочиненій М. А. Максимовича. Томъ І: Отдълъ историческій. К., 1876. С. 208-216.

Максимович, 2004e - Максимович М. Сказаніе о гетмань Петрђ Сагайдачномъ // Максимович М. Вибрані твори з історії Київської Русі, Києва і України. К.: Вища школа, 2004. С. 255-280.

Максимович, 2004f - Максимович М. Сказаніе о Коліивщинъ // Максимович М. Вибрані твори з історії Київської Русі, Києва і України. К.: Вища школа, 2004. С. 373-399.

Максимович, $1877 \mathrm{c}$ - Максимовичъ М. Топографическія замътки кіевлянина // Собраніе сочиненій М. А. Максимовича. Томъ II: ОтдЂлы: историко-топографическій, археологическій и этнографическій. К., 1877. С. 39-49.

Рябчук, 2000 - Рябчук М. Західники мимоволі: парадокси українського нативізму // Рябчук М. Від Малоросії до України: парадокси запізнілого націєтворення. К.: Критика, 2000. С. 66-102. 


\section{REFERENCES}

Valitskyi, 1998 - Valitskyi A. In the captivity of conservatory Utopia: the structre and modifications of the Russian Slavophile mood. K.: Osnovy, 1998. 710 s. [in Ukrainian]

Maksimovich,1876a - Maksimovichy M. Bubnovskaya sotnya [The Bubniv company] // Sobranie sochineniy M. A. Maksimovicha. Tom I. Otdel istoricheskiy. K.,1876. S. 747-834. [in Russian]

Maksimovich, 1880a - Maksimovichy M. Istoriya drevney russkoy slovesnosti [A history of the ancient Rus' literature] // Sobranie sochineniy M. A. Maksimovicha. Tom III. Yazyikoznanie. Istoriya slovesnosti. K., 1880. S. 346-479. [in Russian]

Maksimovich,1880b - Maksimovichy M. Kritiko-istoicheskoe izsledovanie o russkom yazyike [A critical-historical study of the Russian language] // Sobranie sochineniy M. A. Maksimovicha. Tom III: Yazyikoznanie. Istoriya slovesnosti. K., 1880. S. 3-24. [in Russian]

Maksimovich, 2004a - Maksimovich M. Listi / Upor. i vst. st. V. Korotkogo [Letters]. K.: Libid, 2004. 312 s. [in Ukrainian]

Maksimovich, 2004b - Maksimovich M. Ob uchastii i znachenyii Kieva v obschey jizni Rossii [On Kiev's participation and significance in Russias common life] // Maksimovich M. Vybrani tvory z istorii Kyivskoi Rusi, Kyieva i Ukrainy. K.: Vischa shkola, 2004. S. 144-158. [in Russian]

Maksimovich,1877a - Maksimovichy M. O lavrskoy mogilinskoy shkole [On the Laura Mohyla academy] // Sobranie sochineniy M. A. Maksimovicha. Tomy II: Otdel: istoriko-topograficheskiy, arheologicheskiy i etnograficheskiy. K., 1877. S. 210-215. [in Russian]

Maksimovich, 2004c - Maksimovich M. O mnimom zapustenii Ukrainyi v nashestvie Batyievo i naselenii eya novoprishlyim narodom (Pismo M. P. Pogodinu) [On a make-belief desertion of Ukkraine in Baty's time and its inhabitation with the newly arrived people] // Maksimovich M. Vybrani tvory z istorii Kyivskoi Rusi, Kyieva i Ukrainy. K.: Vischa shkola, 2004. S. 130-141. [in Russian]

Maksimovich,1877b - Maksimovichy M. O nadgrobiyah v Pecherskom monastyire [On the graves in Pecherskyi monastery] // Sobranie sochineniy M. A. Maksimovicha. Tomy II: Otdel: istorikotopograficheskiy, arheologicheskiy i etnograficheskiy. K., 1877. S. 216-237. [in Russian]

Maksimovich, 2004d - Maksimovich M. Otkuda idet Russkaya zemlya, po skazaniyu Nestorovoy povesti i po drugim starinnyim pisaniyam russkim [From whence the Rus'land derives]//Maksimovich M. Vybrani tvory z istorii Kyivskoi Rusi, Kyieva i Ukrainy. K.: Vischa shkola, 2004. S. 46-115. [in Russian]

Maksimovich, 1876b - Maksimovichy M. Pisma o knyazyah Ostrojskih (K grafine A. D. Bludovoy) [The letters about the Ostrih princes] // Sobranie sochineniy M. A. Maksimovicha. Tom I: Otdel istoricheskiy. K., 1876. S. 164-195. [in Russian]

Maksimovich, 1876c - Maksimovichy M. Rodoslovnyiya zapiski kievlyanina [The lineage records of a Kievan] // Sobranie sochineniy M. A. Maksimovicha. Tom I: Otdel istoricheskiy. K., 1876. S. 208-216. [in Russian]

Maksimovich, 2004e - Maksimovich M. Skazanie o getmane Petre Sagaydachnom [The tale of Hetman Petro Sahaidachnyi] // Maksimovich M. Vybrani tvory z istorii Kyivskoi Rusi, Kyieva i Ukrainy. K.: Vischa shkola, 2004. S. 255-280. [in Russian]

Maksimovich, 2004f - Maksimovich M. Skazanie o Koliivschine [The tale of the Koliyivshchyna] // Maksimovich M. Vybrani tvory z istorii Kyivskoi Rusi, Kyieva i Ukrainy. K.: Vischa shkola, 2004. S. 373-399. [in Russian]

Maksimovich, 1877c - Maksimovichy M. Topograficheskiya zametki kievlyanina [The topographic records of a Kievan] // Sobranie sochineniy M. A. Maksimovicha. Tom II: Otdelyi: istorikotopograficheskiy, arheologicheskiy i etnograficheskiy. K., 1877. S. 39-49. [in Russian]

Riabchuk, 2000 - Riabchuk M. Zakhidnyky mymovoli: paradoksy ukrainskoho natyvizmu [ProWesterners unwillingly: the paradoxes of Ukrainian nativism ] // Riabchuk M. Vid Malorosii do Ukrainy: paradoksy zapizniloho natsiietvorennia. K.: Krytyka, 2000. S. 66-102. [in Ukrainian]

Стаття надійшла до редакиіï 06.04.2018 p. 